\title{
Magnetic anomalies in East Antarctica: a window on major tectonic provinces and their boundaries
}

\author{
A. V. Golynsky \\ VNIIOkeangeologia, 1, Angliysky Avenue, St.-Petersburg, 190121, Russia. (sasha@vniio.nw.ru)
}

\begin{abstract}
An analysis of aeromagnetic data compiled within the Antarctic Digital Magnetic Anomaly Project (ADMAP) yields significant new insight into major tectonic provinces of East Antarctica. Several previously unknown crustal blocks are imaged in the deep interior of the continent, which are interpreted as cratonic nuclei. These cratons are fringed by a large and continuous orogenic belt between Coats Land and Princess Elizabeth Land, with possible branches in the deeper interior of East Antarctica. Most of the crustal provinces and boundaries identified in this study are only in part exposed. More detailed analyses of these crustal provinces and their tectonic boundaries would require systematic acquisition of additional high-resolution magnetic data, because at present the ADMAP database is largely inadequate to address many remaining questions regarding Antarctica's tectonic evolution.
\end{abstract}

Citation: Golynsky, A. V. (2007), Magnetic anomalies in East Antarctica and surrounding regions: a window on major tectonic provinces and their boundaries, in Proceedings of the $10^{\text {th }}$ ISAES, edited by A. K. Cooper and C. R. Raymond et al., USGS Open-File Report 2007-1047, Short Research Paper 006, 4 p.; doi:10.3133/of2007-1047.srp006.

\section{Introduction}

The geology of the ice-covered interior of the East Antarctic Shield is poorly known and inferences about its composition and history are based on extrapolating scarce outcrops from the coastal regions towards the interior of the continent. It is clear that the shield is composite in nature (Kamenev, 1993; Tingey, 1991) although great uncertainties remain in the location of tectonic boundaries beneath the East Antarctic Ice Sheet due to the general paucity of outcrops and the limited amount of precise and exhaustive geochronology data. In this respect aeromagnetic data may help to reduce ambiguities associated with possible basement province correlations in East Antarctica.

Interpretations of magnetic anomaly data for isolated regions of the Antarctic continent are broadly available. However, in the absence of a continental-scale compilation it has so far not been feasible to analyze the regional structure and composition of the East Antarctic Shield, a key centerpiece of early supercontinents such as Gondwana and Rodinia (Hoffman, 1991; Dalziel, 1991; Moores, 1991). An improved knowledge of East Antarctica is a vital step forward towards understanding continental growth spurts during Precambrian times and associated global processes such as magmatism, accretionary and collisional tectonics and continental break-up (Fitzsimons, 2000a; Rogers, 1996; Unrug, 1996).

This paper focuses on the interpretation of a magnetic anomaly map for part of East Antarctica and surrounding regions (Figure 1), which was compiled within the Antarctic Digital Magnetic Anomaly Project (Golynsky et al., 2001; Johnson et al., 1997). The ADMAP compilation merged all available magnetic survey data collected by the international community from the International Geophysical Year 1957-58 to 1999 and provides a unique window on basement geology, structural architecture and tectonic evolution of the Antarctic crust (Golynsky et al. 2006a).

\section{Interpretation}

Many known tectonic provinces of East Antarctica are characterized by different magnetic patterns that reflect various factors: their ages and lithologies, the degree of reworking, deformations and metamorphic variations (Finn et al., 2006; Golynsky et al., 2006b; Damaske \& McLean, 2005; Ferraccioli et al., 2005; Golynsky and Aleshkova, 2000).

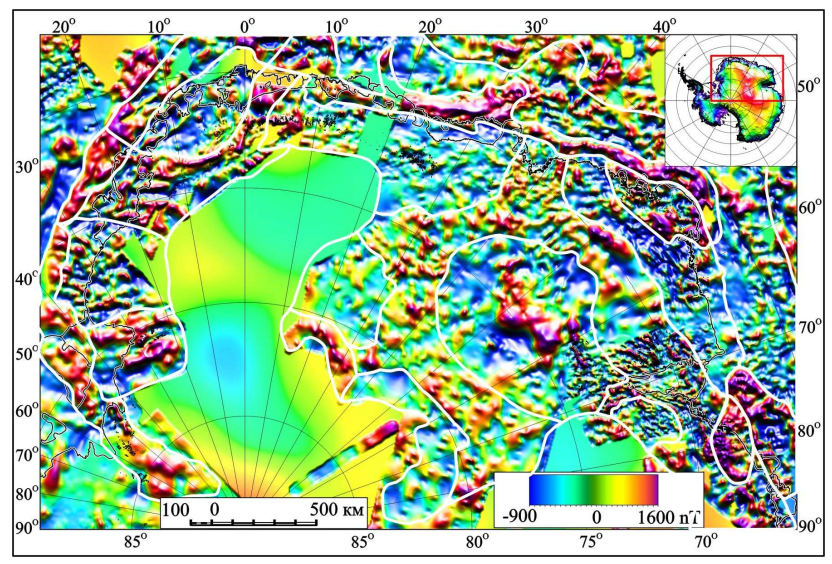

Figure 1. Magnetic anomaly map of East Antarctica and surrounding regions (Golynsky et al., 2001). The insert shows the location of study area in Antarctica. Boundaries between major crustal provinces are shown by white colour. For place names see Figure 2.

Well-defined zonations and distinctive patterns of magnetic anomalies are recognized in Western Dronning Maud Land (WDML, Figure 2), where a broad featureless magnetic low and weak linear short-wavelength magnetic anomalies delineate the extent of the Archean to MidProterozoic Grunehogna Province that most likely represents a fragment of the Zimbabwe-Kaapvaal Craton (e.g. Groenewald et al., 1991; Martin and 1986). It is rimmed by the c. 1.1 Ga Namaqua-Natal-Maud Belt that is characterised by elongate, craton-parallel and highamplitude positive and negative anomalies. 
In Heimefrontfjella, the characteristic anomaly pattern of the Namaqua-Natal-Maud Belt terminates abruptly along a major transpressional shear zone (Golynsky \& Jacobs, 2001). This shear zone separates Mesoproterozoic rocks with a strong Pan-African tectonothermal overprint to the east from unaffected rocks to the west. It has been interpreted as the western front of the East African/Antarctic Orogen (EAAO), which is at a right angle to the Ross Orogen of the Transantarctic Mountains (Tessensohn, 1997; Kleinschmidt and Buggisch, 1994).

The southern boundary of the Maud Belt is not exposed, but the aeromagnetic data south of Heimefrontfjella indicate an abrupt change of the magnetic anomaly pattern over the Coats Land Block (Golynsky and Aleshkova, 2000). The Coats Land block is characterized by a peculiar broken anomaly pattern with isolated short-wavelength highs aligning in narrow zones of variable directions and extensions and therefore is considerably different from the Maud Belt. It is flanked by wide belts of pronounced regional magnetic lineations. In the north of Coats Land this is a series of moderateamplitude magnetic highs and lows mapped over WDML, and in the south there are regional highs of the Shackleton Range crustal block. The western boundary of the Coats Land block is marked by a number of prominent circular anomalies up to $600 \mathrm{nT}$ located in an arcuate zone of high-intensity magnetic gradients that trend subparallel to the coast and supposedly correspond to a number of faults in the basement (Golynsky and Aleshkova, 2000).

The Shackleton Range crustal block (belt?) is aeromagnetically different from the Coats Land block and is characterized by positive anomalies of up to $500 \mathrm{nT}$ amplitude (Golynsky and Aleshkova, 2000). It is highly likely that it continues laterally to $15^{\circ} \mathrm{E}$ and possibly further to the east where a similar magnetic anomaly pattern is observed. The Shackleton block is composed by the Precambrian Stratton and Pioneers groups and by Neoproterozoic sedimentary rocks. The Stratton and Pioneers Groups have undergone a strong tectono-thermal overprint at $\sim 500 \quad \mathrm{Ma}$ and thrusted over the Palaeoproterozoic Read basement that lacks a lower Palaeozoic overprint (Tessensohn, 1997). Neoproterozoic sedimentary rocks together with mafic and ultramafic rocks indicate that the Shackleton Range might contain a late Neoproterozoic/early Palaeozoic suture zone along which an ocean may have closed by sinistral transpression (Talarico et al., 1999). It is obvious that geomagnetic patterns of the Pan-African structures in the Heimefrontfjella and in the Shackleton Range are comparatively co-linear.

Smooth and predominantly low amplitude negative magnetic anomalies, punctuated by local shortwavelength anomalies characterize central and eastern Dronning Maud Land (Golynsky et al., 2001; Damaske, 1999). The majority of local anomalies are associated with voluminous Pan-African post-tectonic granitoids. The coastal outcrops of this region, all indicate a
Grenville-age basement that underwent different degrees of Pan-African reworking (e.g. Shiraishi et al., 1994; Jacobs et al., 1998), with a possible n Early Palaeozoic, yet undiscovered suture hidden under the ice sheet. Identification of crust with no overprint of c. $550 \mathrm{Ma}$ within this part of the EAAO is not possible with the existing aeromagnetic data.

In Enderby Land, a nearly oval belt of mostly positive anomalies differentiates the Archean Napier Craton from the negative magnetic anomalies over the Mesoproterozoic Rayner Belt to the south that continues towards MacRobertson Land. Together with the magnetic anomaly fabric of the northern Prince Charles Mountains (PCM) and neighboring areas over the eastern shoulder of the Lambert Rift this anomaly belt forms a continentalscale structure that runs from the Prince Olav Coast towards Princess Elizabeth Land. In our interpretation it delimits and characterizes the inner structure of the Beaver-Rayner Mesoproterozoic mobile belt (Golynsky et al., 2006b). Similar magnetic anomaly patterns are clearly recognized in the interior of East Antarctica on the basis of reconnaissance surveys (Figure 1). Both magnetic subdivisions define the extent of the Archean Ruker Craton of the southern Prince Charles Mountains that is associated with low-amplitude anomalies on a negative background.

The intense short-wavelength, high-amplitude positive anomalies that extend around the Vestfold Hills are presumably associated with a high-grade metamorphic Late Archean craton. The northern Prince Charles Mountains display a predominantly northeasterly trending magnetic fabric that continues to the eastern shoulder of the Lambert Rift and is related with the Proterozoic charnockite-granulite terrane of the Beaver Terrane (Kamenev et al., 1993). Elongate and moderate magnetic banding appears to characterize the Late Proterozoic rocks of the Fisher sub-terrane. The prominent alternating system of linear NE-SW positive and negative anomalies over the eastern shoulder of the Lambert Rift may reflect the western boundary of the newly discovered Princess Elizabeth Land cratonic block, like those observed in the Vestfold Hills block and the Ruker Terrane. It is highly likely that they belong to a single stable proto-craton of Archaean to Paleoproterozoic age.

Similarity in magnetic anomaly characteristics does not necessarily indicate basements and/or provinces of similar lithologies and ages, but it does suggest sources with similar magnetic properties and dimensions. Hence based on the similarity of magnetic anomaly patterns over the southern Prince Charles Mountains and western Dronning Maud Land regions we have attempted to establish two new crustal provinces of cratonic nature. They correspond to the deep interior of East Antarctica and are located close to the Gamburtsev Subglacial Mountains and over the Low Plain (Figure 2). At present this suggestion is entirely speculative but further 
aeromagnetic surveys and drilling could support or disprove it.

\section{Discussion}

In western Dronning Maud Land the craton/mobile belt boundary is not exposed but clearly recognized in the aeromagnetic data (Golynsky and Aleshkova, 2000). The intersections of the craton/mobile belt boundary with the present coastlines in Antarctica and Africa can be used as piercing points for the tight juxtaposition of the two continents (Hunter et al., 1991). The data show that the combination of aeromagnetic mapping along with detailed geological work is a powerful method to delineate the extent of the East Antarctic orogen in poorly exposed Antarctica.

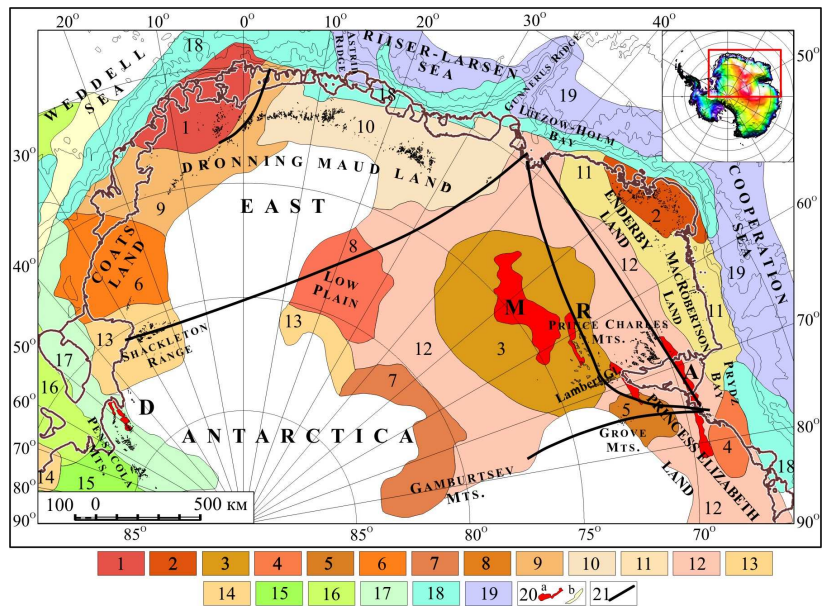

Figure 2. Major crustal provinces of East Antarctica identified in this study by using the ADMAP map. 1-8 cratonic nuclei: 1 - Grunehogna, 2 - Napier, 3 - Ruker, 4 - Vestfold-Rauer, 5 - Princess Elizabeth, 6 - Coats, 7-8 unnamed; 9-13 - mobile belts: 9 - Maud, 10 - CDML, 11-12 - Rayner-Beaver, 13 - Shackleton; 14-19 - crustal provinces which are beyond the scope of this paper; $20-$ prominent magnetic anomalies: $\mathrm{a}-$ positive, $\mathrm{b}$ - negative; 21 - proposed sutures (after e.g. Boger et al., 2001; Wilson et al., 1997; Shackleton, 1996); Prominent magnetic anomalies: A - Amery, D - Dufek, M - Mellor, $\mathrm{R}$ - Ruker. The insert shows the location of study area in Antarctica.

Un-metamorphosed late Mesoproterozoic rocks in Coats Land are exposed in few nunataks that overlie a basement of unknown age. In view of the fact that these rocks are slightly older ( 1110 Ma; Gose et al., 1997) than the metamorphism in the Maud Belt ( 1090-1060 Ma; Jacobs et al., 2003) the buried basement of the Coats Land block might be Archean to early Mesoproterozoic in age (Jacobs et al., 2003; Golynsky and Aleshkova, 2000). The dome configuration of the Coats Land crustal block along with its magnetic anomaly pattern support the notion that it represents a relatively stable Pre-Grenvillian block, which could have acted as a buttress during strong deformation in the surrounding mobile belts, and which primary basement structure was strongly altered by a variety of tectonothermal events imprinted in the present magnetic anomaly patterns.

The eastern margin of the East African-Antarctic orogen is probably exposed in the Shackleton Range. However it is still unclear whether the Pan-African tectono-metamorphic overprint in the area between Heimefrontfjella and the Shackleton Range represents a dense network of Pan-African shear zones and thrusts, or whether it was caused through reworking with a few arrested lenses of unaffected material in between. Continuity and linearity of high-intensity magnetic anomalies over the Shackleton Range and eastern icecovered regions suggests that the latter is more likely. Based on the consideration that the Haag crustal block displays a similar magnetic signature, as that of the Shackleton Range, it can be concluded that this continuous tectonic structure represents the long-lived mobile belt that was active from the early Proterozoic to early Paleozoic time.

The aeromagnetic data indicate that the Pan-African mobile belt in Prydz Bay is obviously not linked with Lützow-Holm Bay. Neither does it extend inland towards the Mawson Escarpment or Grove Mountains (Golynsky et al., 2006), thereby indicating that East Gondwana should not be subdivided into separate Indo-Antarctic and Australo-Antarctic sectors, as recently was suggested by a number of authors (e.g. Boger et al., 2001). Identifying the exact path of the Cambrian belt beyond the central part of the Mawson Escarpment where high-resolution isotopic data are available remains problematic. As to the Grove Mountains crustal block itself, it is clearly discernible in the aeromagnetic data and can be considered as a region that underwent either Grenvillian or Pan-African (or both) tectonism and reworking.

The open problem of identifying any Pan-African sutures in the southern PCM, Prydz Bay, WDML and Lützow-Holm Bay regions is possibly due to the fact that the early Paleozoic tectonic processes in this part of East Antarctica were predominantly of intraplate origin and hence did not involve formation of mantle-derived rocks (with the exception of a poorly dated ophiolite assemblage in the Shackleton Range). These tectonic processes were responsible for the generation of large amounts of anatectic melts resulting in the emplacement of predominantly mid-crustal anorogenic intrusions and were accompanied by transtensional and thrust tectonics in the upper crust.

\section{Conclusions}

Aeromagnetic data have a profound impact on our knowledge of the Precambrian provinces of the East Antarctic Shield and image the otherwise largely unknown subglacial boundaries between the stable Archean blocks and mobile belts of different ages.

Most of the crustal provinces, boundaries and structures identified in this paper are only in part exposed. 
An improved characterization of these crustal provinces and their boundaries requires systematic acquisition of new high-resolution magnetic data, because at present the ADMAP database is still inadequate to address many details of Antarctica's evolution and its role in global crustal growth processes.

Interpretation of regional magnetic anomaly data reveals that the previously postulated (Yoshida, 1995; Kamenev, 1993) single Mesoproterozoic orogenic belt, which was inferred to link WDML to Western Australia (Pinjarra Orogen) and/or to southwestern Australia (Albany-Fraser Orogen) needs in a revision. As to the models invoking the assembly of East Gondwana during the Pan-African Orogeny (e.g. Fitzsimons, 2000b), they should be re-examined in light of aeromagnetic imprints as well. A number of key areas for future aerogeophysical investigation of the East Antarctic lithosphere have also been identified between Coats Land and Princess Elizabeth Land.

Acknowledgments The author is pleased to acknowledge N. D. Aleshkova, G. E. Grikurov and R. G. Kurinin for fruitful discussions regarding this work. The paper was greatly improved by reviews of the original manuscript by F. Ferraccioli and M. Yoshida. Helpful review of the manuscript by M. Studinger is gratefully acknowledged.

\section{References}

Boger, S. D, C. J. L. Wilson \& C. M. Fanning (2001), Early Paleozoic tectonism within the east Antarctic craton: the final suture between east and west Gondwana? Geology, 29, 463-466.

Damaske, D. (1999), Merging aeromagnetic data collected at different levels the GEOMOD survey, Annali Di Geofisica, vol. 42, N. 2, 153159.

Damaske, D. and M. McLean (2005), An aerogeophysical survey south of the Prince Charles Mountains, East Antarctica, Terra Antartica, 12(2), 87-98

Ferraccioli, F., P. C. Jones, M. L. Curtis, P. T. Leat, and T. R. Riley (2005), Tectonic and magmatic patterns in the Jutulstraumen rift (?) region, East Antarctica, as imaged by high-resolution aeromagnetic data, Earth Planets Space, 57, 767-780.

Finn, C. A., J. W. Goodge, D. Damaske, C. M. Fanning (2006), Scouting craton's edge in paleo-Pacific Gondwana, in Antarctica Contributions to Global Earth Sciences, edited by D. K. Fütterer, D. Damaske, G. Kleinschmidt, H. Miller, F. Tessensohn, SpringerVerlag, Berlin Heidelberg New York, 165-174.

Fitzsimons, I. C. W. (2000a), A review of tectonic events in the East Antarctic Shield and their implications for Gondwana and earlier supercontinents, J. African Earth Sci., 31, 3-23.

Fitzsimons, I. C. W. (2000b), Grenville-age basement provinces in East Antarctica: Evidence for three separate collisional orogens, Geology, $28,879-882$.

Golynsky, A. V. and N. D. Aleshkova (2000), New Aspects of Crustal Structure in the Weddell Sea Region from Aeromagnetic Studies, Polarforshung, 67, 133-141.

Golynsky, A., M. Chiappini, D. Damaske, F. Ferraccioli, J. Ferris, C. Finn, M. Ghidella, T. Ishihara, A. Johnson, H. R. Kim, L. Kovacs, J. LaBrecque, V. Masolov, Y. Nogi, M. Purucker, P. Taylor, and M. Torta (2001), ADMAP - Magnetic Anomaly Map of Antarctic, in BAS (Misc.) 10, edited by P. Morris and R. von Frese, Cambridge, BAS.

Golynsky A. and J. Jacobs (2001), Grenville-Age versus Pan-African Magnetic Anomaly imprints in Western Dronning Maud Land, East Antarctica, The Journal of Geology, vol. 109, 136-142.

Golynsky, A., M. Chiappini, D. Damaske, F. Ferraccioli, C. Finn, M. Ghidella, T. Ishihara, H. R. Kim, L. Kovacs, V. Masolov, P. Morris,
Y. Nogi, R. von Frese (2006a), ADMAP - a digital magnetic anomaly map of the Antarctic, in Antarctica - Contributions to Global Earth Sciences, edited by D. K. Fütterer, D. Damaske, G. Kleinschmidt, H. Miller, F. Tessensohn, Springer-Verlag, Berlin Heidelberg New York, 109-116.

Golynsky, A. V., V. N. Masolov, V. S. Volnukhin, and D. A. Golynsky (2006b), Crustal provinces of the Prince Charles Mountains region and surrounding areas in a light of aeromagnetic data, in Antarctica Contributions to Global Earth Sciences, edited by D. K. Fütterer, D. Damaske, G. Kleinschmidt, H. Miller, F. Tessensohn, SpringerVerlag, Berlin Heidelberg New York, 83-94.

Gose, W. A., M. A. Helper, J. N. Connelly, F. E. Hutson, I. W. D. Dalziel (1997), Paleomagnetic data and U-Pb isotopic age determinations from Coats Land, Antarctica Implications for late Proterozoic plate reconstructions, J. Geophys. Res., Apr. 10, 102 (B4), 7887-7902.

Hunter, D. R., J. R. Krynauw, A. le Roex, P. B. Groenewald, C. Harris, B., Corner, G. H. Grantham, H. W. Bergh, and A. B. Moyes, (1991), A recent history of South African earth science research in Antarctica and adjacent regions, S. Afr. T. Nav. Antarkt., Vol., 21 No 2, 173-183.

Jacobs J., C. M. Fanning, W. Bauer (2003), Timing of Grenville-age vs. Pan-African medium- to high grade metamorphism in western Dronning Maud Land (East Antarctica) and significance for correlations in Rodinia and Gondwana, Prec. Res., 125, 1-20.

Jacobs, J., C. M. Fanning, F. Henjes-Kunst, M. Olesch, H-J. Paech (1998), Continuation of the Mozambique Belt into East Antarctica Grenville-age Metamorphism and polyphase Pan-African high-grade events in Central Dronning Maud Land, The Journal Geology, Vol. 106, 385-406.

Johnson, A. C., R. R. B. von Frese, and ADMAP Working Group (1997), Magnetic map will define Antarctica's structure, EOS, Transactions American Geophysical Union, May 6, 78(18), 185.

Kamenev, E. N. (1993), Structure and evolution of the Antarctic shield in Precambrian, in Gondwana Eight: Assembly, Evolution and Dispersion, edited by R. H. Findley, R. Unrug, M. R. Banks, \& J. J. Veevers, A.A. Balkema, Rotterdam, 141-151.

Kamenev, E. N., A. V. Andronikov, E. V. Mikhalsky, N. N. Krasnikov, and K. Stüwe (1993), Soviet geological maps of the Prince Charles Mountains, East Antarctic Shield, Aust. J. of Earth Sci., 40, 501-517.

Kleinschmidt, G. and W. Buggisch, (1994), Plate tectonic implications of the structure of the Shackleton Range, Antarctica, Polarforschung, $63,(1), 57-62$.

Martin, A. K., and C. J. H. Hartnady (1986), Plate tectonic development of the south west Indian Ocean: a revised reconstruction of east Antarctica and Africa, J. Geophys. Res., Vol. 91, 4767-4778.

Moores, E. M. (1991), Southwest U.S.-East Antarctica (SWEAT) connection a hypothesis, Geology, 19, 425-428.

Rogers, J. J. W. (1996), A history of continents in the past three billion Years, The Journal of Geology, Vol. 104, 91-107.

Shackleton, R. M. (1996), The final collision zone between East and West Gondwana where is it? J. Afr. Earth Sci., 23271-287.

Shiraishi, K. D. J. Ellis, Y. Hiroi, C. M., Fanning, Y. Motoyoshi, \& Y. Nakai (1994), Cambrian orogenic belt in East Antarctica and Sri Lanka: implications for Gondwana assembly, Journal of Geology, $102,47-65$.

Talarico, F., G. Kleinschmidt, \& F. Henjes-Kunst (1999), First report of an ophiolitic complex in the northern Shackleton Range, Antarctica. Terra Antartica, 6, No. 3/4, 293-315.

Tessensohn, F. (1997), Shackleton Range, Ross Orogen and SWEAT Hypothesis, in The Antarctic Region Geological Evolution and Processes, edited by C. A. Ricci, Terra Antarctica Publication, Siena, 5-12.

Wilson, T., A. M. Grunow, and R. E. Hanson (1997), Gondwana Assembly The review from southern Africa and East Gondwana, J. Geodynamics, 23, 263-286.

Yoshida, M. (1995), Assembly of East Gondwanaland during the Mesoproterozoic and its rejuvenation during the Pan-African period, in India and Antarctica during the Precambrian, edited by M. Yoshida, M, Santosh, Geological Society of India, Memoir, vol. 34, 25-45. 